四国中央部別子地域三波川帯の超マフィック層状岩体に認められる変形構造 :

$$
\text { ブーディンおよびデュープレックス様累重 }
$$

\title{
Deformation structures in layered ultramafic rocks of the Sanbagawa Belt, Besshi area, central Shikoku, southwest Japan: Boudins and duplex-like superposition
}

\author{
山本啓司 ${ }^{*}$ 寺林 優** 小宮 剛*** \\ Hiroshi Yamamoto ${ }^{*}$, Masaru Terabayashi ${ }^{* *}$ and Tsuyoshi Komiya ${ }^{* * *}$
}

2010 年 10 月 26 日受付. 2010 年 12 月 10 日受理.

鹿児島大学大学院理工学研究科

Graduate School of Science and Engineering, Kagoshima University

** 香川大学工学部

Faculty of Engineering, Kagawa University

**** 東京大学大学院総合文化研究科

Graduate School of Arts and Sciences, The University of Tokyo

Corresponding author; H. Yamamoto, hyam@sci.kagoshima-u.ac.jp

ブーディンとデュープレックスは砕屑性堆積岩層に一般的に認めら れる変形構造である. 四国中央部の東赤石山系 (Higashi-Akaishi mountains）の「権現越（Gongengoe-pass）」は，東赤石カンラン岩 体と五良津角閃岩体の境界付近にあたる．権現越を含む尾根筋の北西 側斜面には成層した超マフィック岩類が広く露出している. 成層構造 は主としてマグマ溜り内部での結晶集積によって生じたと考えられる. この超マフィック層状岩体には砕屏性堆積岩層に認められるものと形

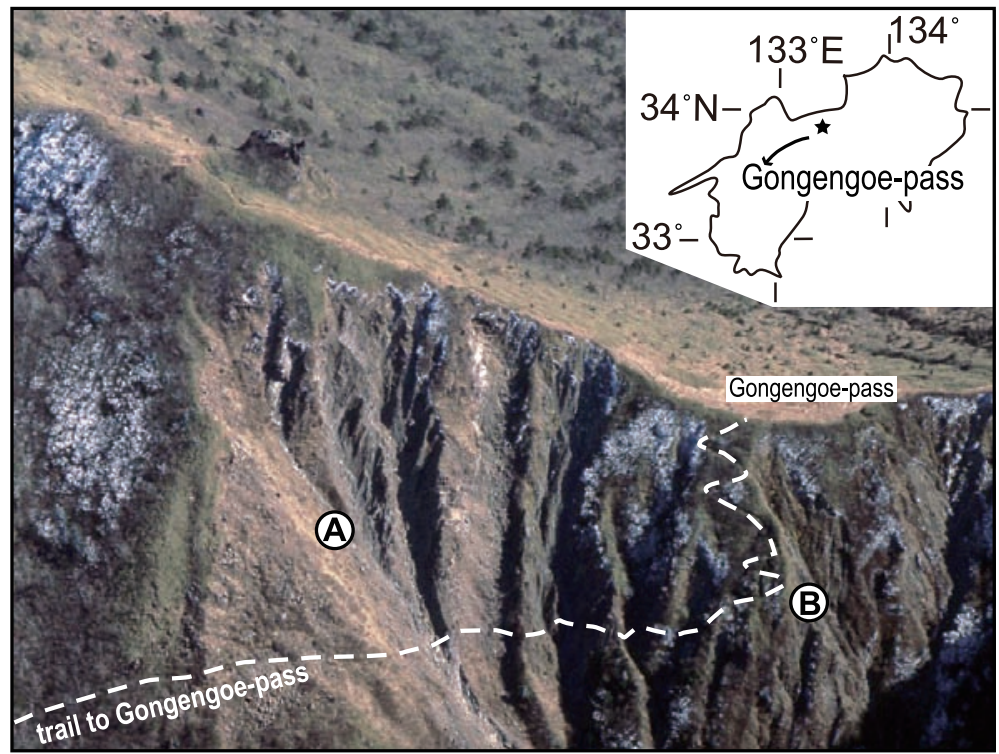

態上同等なブーディンおよびデュープレックス様の変形構造が形成さ れている (Yamamoto et al., 2004)。層状の深成岩体にデュープレッ クスのような構造的累重が認められることは, 層状岩体の化学組成や 微細構造を解析する際には後生的変形によって同一層の繰り返しが生 じ得ることに注意を払う必要があることを示している. これらの露頭付 近を通る登山道は斜面の崩落によって荒れてしまい, 通行困難になり つつある. 現地では斜面上部からの落石に注意を要する。Fig. 1 の斜 航空写真はアジア航測株式会社にご提供いただいた. 査読者の青矢睦 月氏，編集担当の大藤茂氏には本稿の改善に役立つコメントをいただ いた。

文献

Yamamoto, H., Okamoto, K., Kaneko, Y. and Terabayashi, M., 2004, Southward extrusion of eclogite-bearing mafic-ultramafic bodies in the Sanbagawa belt, central Shikoku, Japan. Tectonophysics, 387, 151 -168 .

Fig. 1. Aerial photograph of the observed sites A and B. Width of the view is about $260 \mathrm{~m}$, looking east. Sites A and B are located at $33^{\circ} 52^{\prime} 45^{\prime \prime} \mathrm{N}, 133^{\circ} 23^{\prime} 8^{\prime \prime} \mathrm{E}$ and $33^{\circ} 52^{\prime} 41^{\prime \prime} \mathrm{N}, 133^{\circ} 23^{\prime}$ $5^{\prime \prime} \mathrm{E}$, respectively. Inset map shows location of Gongengoe-pass in Shikoku Island.

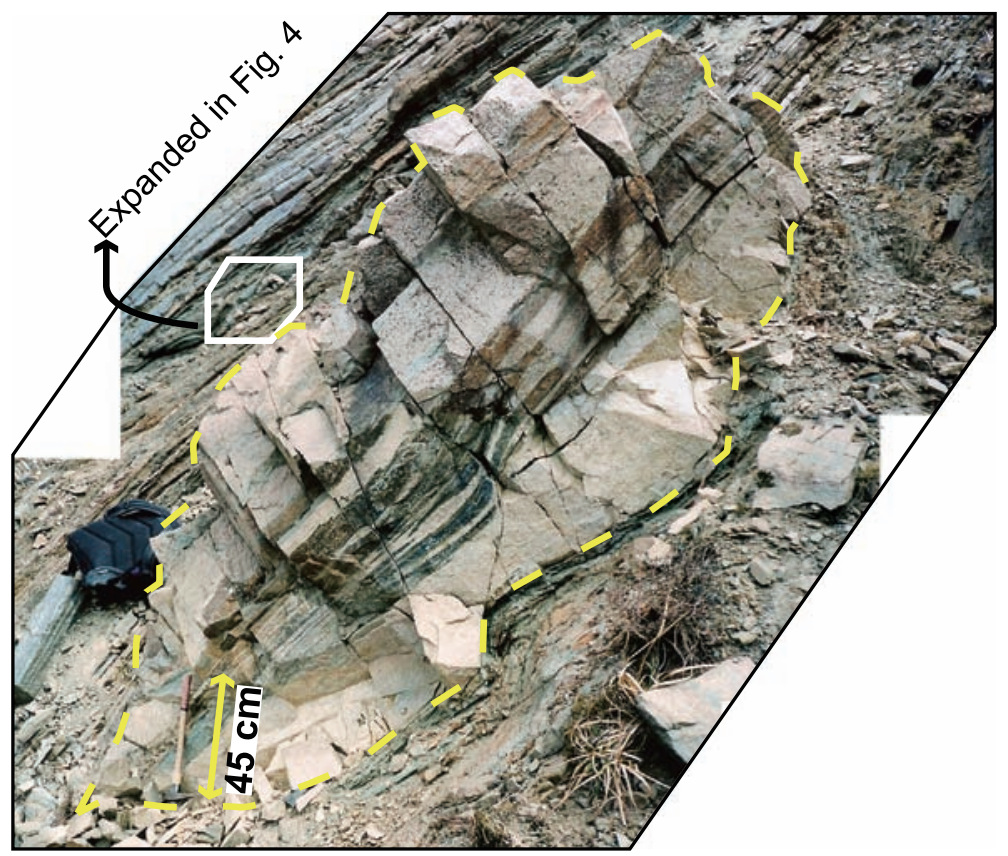

Fig. 2. Large boudin of a garnet pyroxenite layer (outlined by dashed yellow line) in peridotite layers at site A (see Fig. 1 for site location). Hammer in the bottom-left is $45-\mathrm{cm}$ long. 


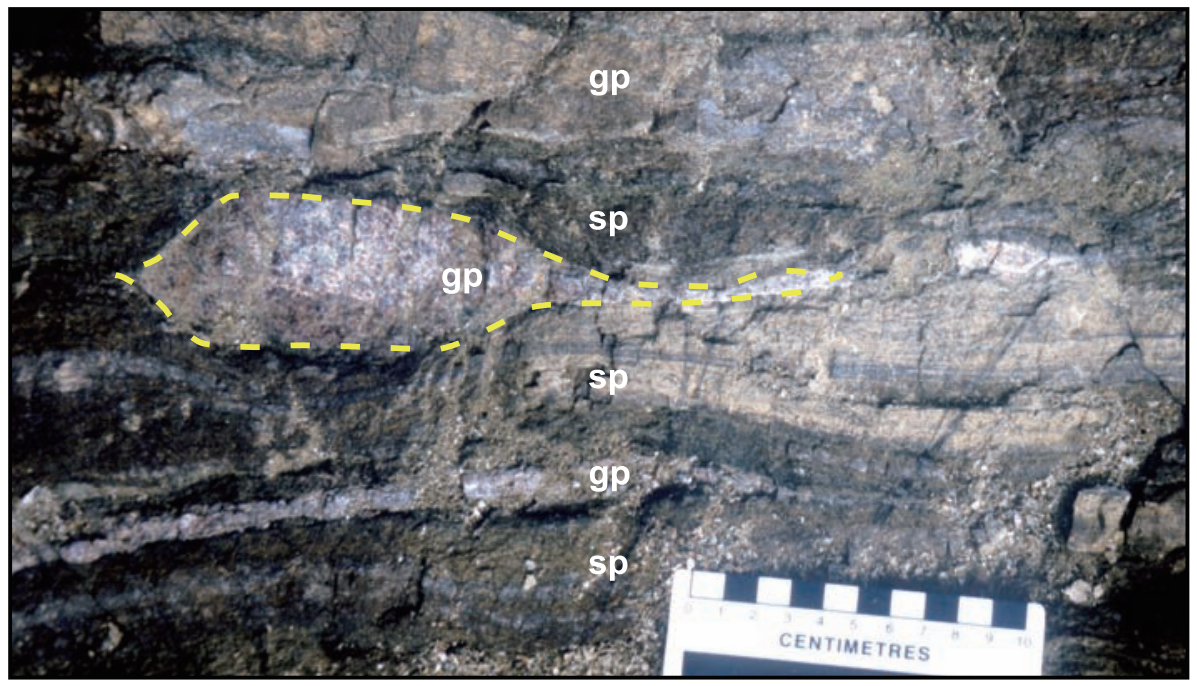

Fig. 3. Boudin of a garnet pyroxenite layer (outlined by dashed yellow line) in alternating garnet pyroxenite (gp) and serpentinized peridotite $(\mathrm{sp})$ layers at site A (see Fig. 1 for site location). Scale in the bottom-right is 10 -cm long.
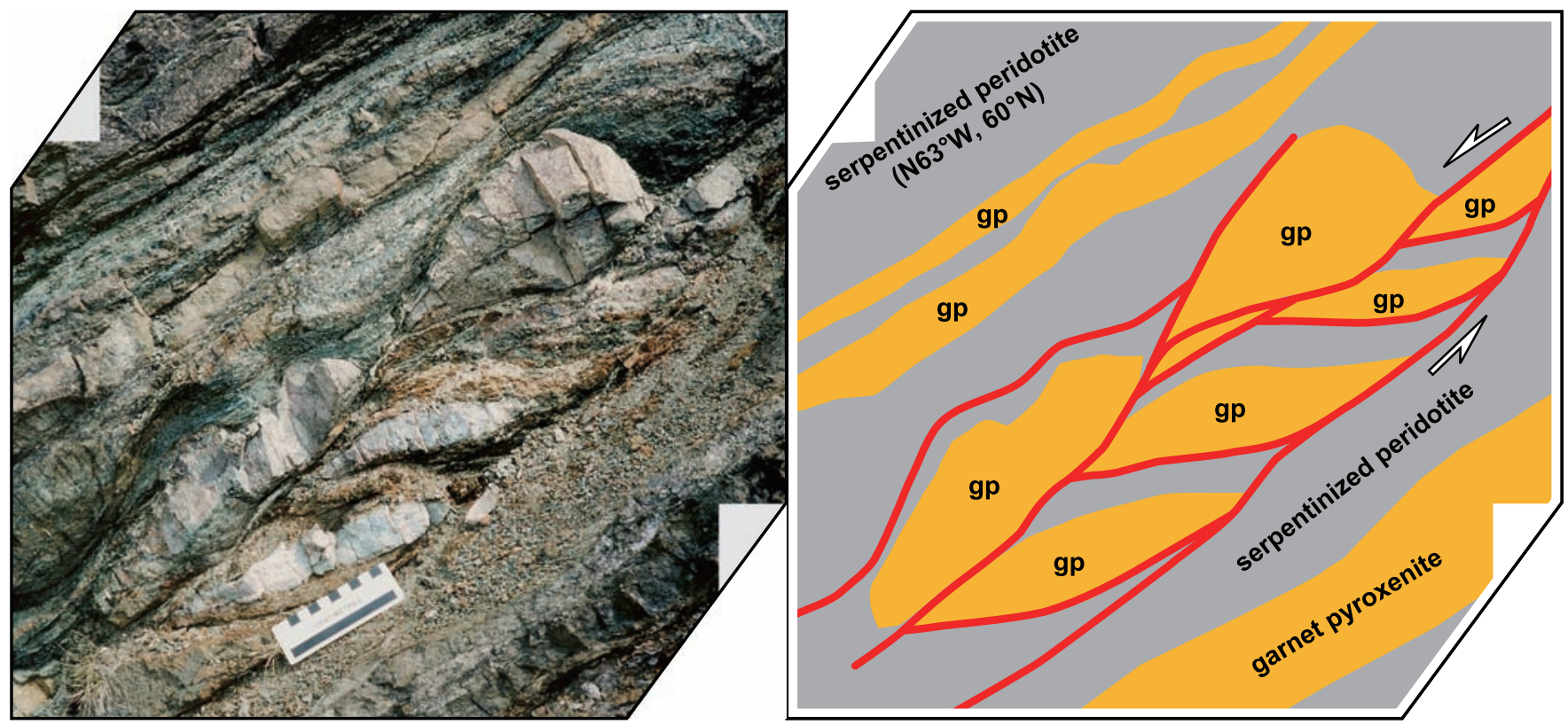

Fig. 4. Photograph (left view) and accompanying sketch (right view) of deformed garnet-pyroxenite and peridotite. Lenticular bodies of garnet-pyroxenite form an array at site A (see Fig. 1 for site location) in the style of a contractional duplex. Red lines indicate traces of the fault or shear zone.

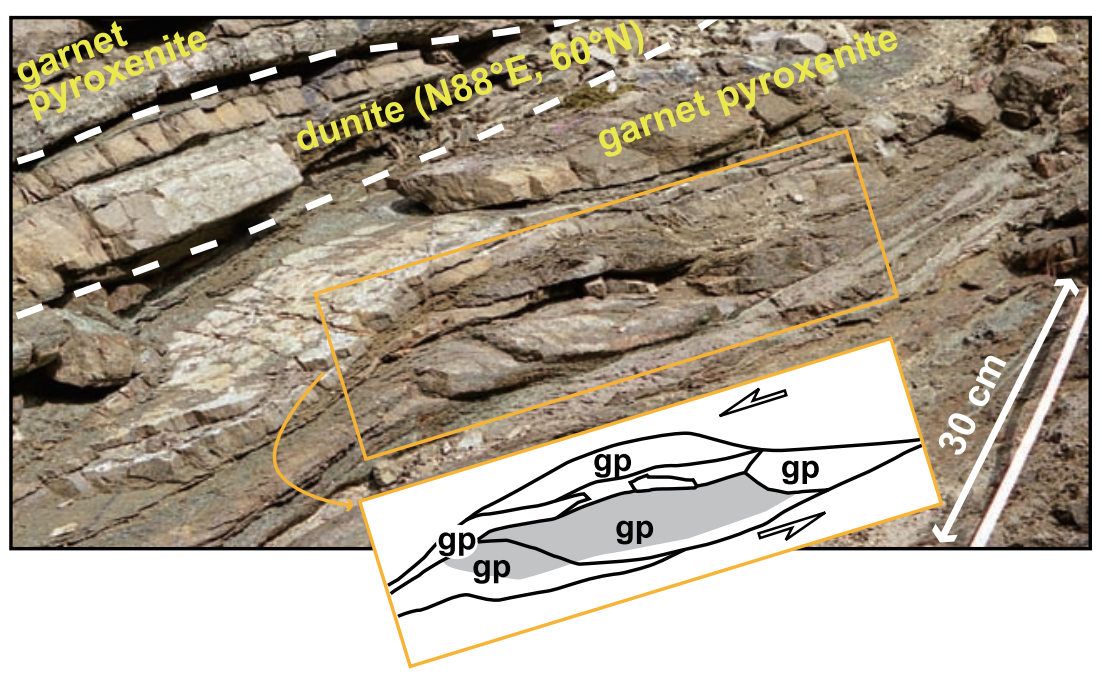

Fig. 5. Layered garnet pyroxenite and dunite at site B (see Fig. 1 for site location). Overlapping sheet-like bodies of garnet pyroxenite (as outlined by the rectangle) are analogous to a contractional duplex (antiformal stack). The inset shows a sketch of the area within the rectangle. Gray shading in the sketch indicates the upper surfaces of two overlapping sheets. The section of white tape at the bottom-right is $30-\mathrm{cm}$ long. 